\title{
GRANULAR CELL TUMOR OF BREAST (CYTOLOGICAL DIAGNOSIS CONFIRMED BY HISTOPATHOLOGY)
}

\author{
Divvya B1, M. Valluvan², B. Krishnaswamy³, P. Viswanathan', R. Baskaran ${ }^{5}$
}

\section{HOW TO CITE THIS ARTICLE:}

Divvya B, M. Valluvan, B. Krishnaswamy, P. Viswanathan, R. Baskaran. "Granular Cell Tumor of Breast (Cytological Diagnosis Confirmed By Histopathology)". Journal of Evolution of Medical and Dental Sciences 2014; Vol. 3, Issue 55, October 23; Page: 12683-12686, DOI: 10.14260/jemds/2014/3680

ABSTRACT: Granular cell tumor is a tumor derived from Schwann cells of peripheral nerves and it can occur throughout the body. About 5\% of granular cell tumors occur in breast and are mostly benign in nature. We report a case of 30 year old female who presented with a swelling in right breast which on histo pathological examination revealed features consistent with granular cell tumor. This case is highlighted to reveal the importance of histopathology in differentiating granular cell tumor from carcinoma breast which is difficult based on clinical, radiological and cytological examination alone.

KEYWORDS: Granular cell tumor, Breast.

CASE REPORT: A 30 year old female presented to the surgical outpatient department with a history of swelling in the right breast for 4 months. She also had complaints of cyclical mastalgia. Examination revealed a solitary swelling measuring $1 \times 0.5 \mathrm{~cm}$ situated in the superficial portion of the upper inner quadrant of right breast. Swelling was firm to hard in consistency and non-tender. It was clinically diagnosed as? Carcinoma breast. Fine needle aspiration cytology was done followed by excision biopsy.

CYTOLOGY: Multiple smears studied reveal hemorrhagic material where round to cuboidal cells were observed. These cells appear bland and contain moderate amount of cytoplasm; nucleus is prominent. These cells were distributed individually and in clumps. Features are suggestive of differential diagnosis in the form of Adnexal tumor or Granular cell tumor. Excision biopsy was needed for categorization.

MACROSCOPY: A single gray yellow, gray brown soft tissue piece measuring $2 \mathrm{x} 1.8 \mathrm{~cm}$ was sent to histopathology. On C/s - well circumscribed gray white areas identified.

MICROSCOPY: Histological study revealed a cellular tumor where tumor cells are present in deep dermal adipose tissue level. Tumor cells were closely packed with moderate amount of granular cytoplasm and nuclei were pin-point in appearance. The tumor was divided into vague organoid pattern by delicate septae. Features were consistent with the diagnosis of Granular cell tumor.

DISCUSSION: Granular cell tumor is a mesenchymal tumor, probably of Schwann cell origin, with tumor cells showing abundant eosinophilic granular cytoplasm. ${ }^{1}$ The first report of granular cell tumor is attributed to Abrikossoff in 1926 localized in the tongue and he proposed origin from striated muscle cells and he termed this lesion as myoblastoma. ${ }^{2}$ Later the cell of origin became controversial until the most widely accepted theory, that of a Schwann cell origin, apparently because of the positivity of the tumor for the S-100 protein, has been putforth. ${ }^{3}$ 
The first description of a mammary granular cell tumor was published in 1931. Granular cell tumor of the breast (GCTB) is most often encountered in women 30 to 50 years old, but it has also been described in adolescents and elderly women with an overall age range of 17 to 74 years old. ${ }^{4}$

The tumor arises from the intra-lobular stroma of the breast. Although virtually all the lesions are benign neoplasms, rare malignant lesions are described. ${ }^{5}$ GCTs have been shown to be nondependent on estrogen and progesterone. ${ }^{6}$

Clinically, most patients will present with a painless, firm, mobile nodule measuring 1 to $2 \mathrm{~cm}$ in size in the upper inner breast quadrant and are often initially diagnosed as having a fibroadenoma or carcinoma. GCTs of the breast are unlikely to be diagnosed correctly on initial examination unless biopsy and pathologic results are obtained. ${ }^{7}$

CYTOLOGICAL FEATURES: It is important to recognize in the aspiration smear the characteristic large cells with abundant granular cytoplasm and fairly monotonous, generally spherical small nuclei without distinguishing features. In smears, a break-up of the cytoplasm is a common feature that results in "naked" nuclei. ${ }^{8}$

MACROSCOPIC FEATURES: Granular cell tumor usually presents as a firm or hard mass. Many of them appear to be well circumscribed. The cut surface is white or gray, or it may have a yellow to tan color. Tumors are generally $3 \mathrm{~cm}$ or smaller. ${ }^{4}$

MICROSCOPIC FEATURES: The tumor is composed of compact nests or sheets of cells that contain eosinophilia cytoplasmic granules. Cell borders are typically well defined, and the cells vary from polygonal to spindly in shape. Nuclei are round to slightly oval with an open chromatin pattern. Nucleoli tend to be prominent.

Although many of the tumors appear grossly circumscribed, microscopic examination usually reveals an infiltrating growth pattern at the margins of the lesion. ${ }^{4}$ The granular appearance of the cytoplasm may be caused by accumulation of secretory granules, mitochondria, or lysosomes. Evidence of granule origin as in folding of cell membrane by a process similar to myelin formation around nerves has been described. ${ }^{9}$

CONCLUSION: Granular cell tumor is a rare benign neoplasm of uncertain origin. Only 5\% of these tumors occur in the breast. Clinically using mammography and ultrasound, these tumors can often simulate more ominous lesions like carcinomas. The main striking histological element is the presence of granular cytoplasm.

\section{REFERENCES:}

1. Farid Moinfar. 123Essentials of Diagnostic Breast Pathology, Springer, Nov 2006. Pg. 382.

2. Abrikossoff A. Ueber Myome ausgehened von der quergestreiften willkuerlichen Muskulatur. Virchows Arch [Pathol Anat] 1926; 260: 215.

3. Rosso R, Scelsi M, Carnevali L. Granular cell traumatic neuroma: a lesion occurring in mastectomy scars. Arch Pathol Lab Med 2000, 124: 709-711.

4. Rosen PP. Rosen's Breast Pathology, 3 $3^{\text {rd }}$ edn. Lippincott Williams \& Wilkins, 2009. Pg. 860. 


\section{CASE REPORT}

5. Uzoaru I, Firfer B, Ray V, Hubbard-Shepard M, Rhee H. Malignant granular cell tumor. Arch Pathol Lab Med 1992, 116: 206-208.

6. Adeniran A, Al-Ahmadie H, Mahoney MC, et al. (2004) Granular cell tumor of the breast: A series of 17 cases and review of the literature. Breast J 10: 528-53.

7. American Society of Clinical Oncology Granular Cell Tumor of the Breast. Clinical and Pathologic Characteristics of a Rare Case in a 14-Year-Old Girl by Nicole De Simone $\Downarrow$, Allison Aggon and Carla Christy, 2011.

8. Koss, Leopold G. Melamed, Myron R. Koss' Diagnostic Cytology and Its Histo pathologic Bases, $5^{\text {th }}$ edn. Lippincott Williams \& Wilkins, 2006. Pg. 1100.

9. Mithal KR, True LD. Origin of granules in granular cell tumor. Intracellular myelin formation with auto digestion. Arch Pathol Lab Med. 1988; 112: 302-303.

\section{CYTOLOGY IMAGES:}

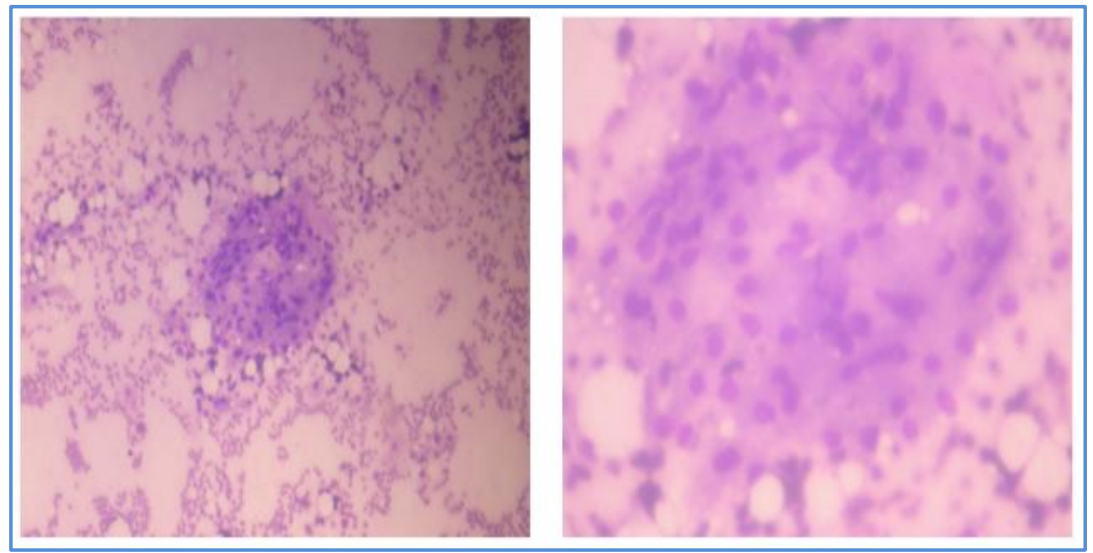

Fig. 1: Giemsa stain 10x

Fig. 2: Giemsa stain 40x

Abundant cytoplasm which is granular in nature with prominent nuclei.

\section{MICROSCOPIC IMAGES:}

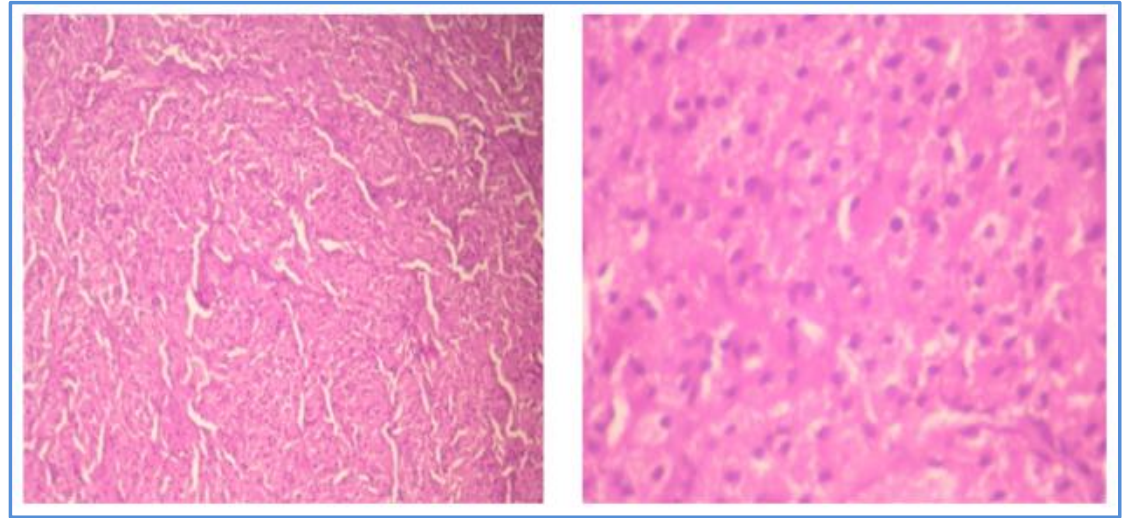

Fig. 3: H \& E stained 10x

Fig. 4: H \& E stained 40x 
Cellular tumor, where tumor cells are round to polygonal in shape with abundant cytoplasm and pin-point nuclei. Vague lobulations are present due to intervening slender fibrous tissue. Cytoplasm is granular in nature.

\section{AUTHORS:}

1. Divvya B.

2. M. Valluvan

3. B. Krishnaswamy

4. P. Viswanathan

5. R. Baskaran

\section{PARTICULARS OF CONTRIBUTORS:}

1. $2^{\text {nd }}$ Year Post Graduate student, Department of Pathology, Rajah Muthiah Medical College, Annamalai University, Chidambaram.

2. $2^{\text {nd }}$ Year Post Graduate Student, Department of Pathology, Rajah Muthiah Medical College, Annamalai University, Chidambaram.

3. Professor, Department of Pathology, Rajah Muthiah Medical College, Annamalai University, Chidambaram.

4. Professor, Department of Pathology, Rajah Muthiah Medical College, Annamalai University, Chidambaram.
5. Professor, Department of Surgery, Rajah Muthiah Medical College, Annamalai University, Chidambaram.

\section{NAME ADDRESS EMAIL ID OF THE CORRESPONDING AUTHOR:}

Dr. P. Viswanathan, Professor, Department of Pathology, Faculty of Medicine, Rajah Muthiah Medical College, Annamalai University, Chidambaram-608002, Tamil Nadu, India.

Email: drpviswanathan2013@gmail.com

Date of Submission: 06/10/2014. Date of Peer Review: 07/10/2014. Date of Acceptance: 16/10/2014. Date of Publishing: 23/10/2014. 